\title{
Inter-annual variations of wet deposition in Beijing from 2014-2017: implications of below-cloud scavenging of inorganic aerosols
}

\author{
Baozhu Ge ${ }^{1,5}$, Danhui Xu ${ }^{1,6}$, Oliver Wild ${ }^{2}$, Xuefeng Yao ${ }^{3}$, Junhua Wang ${ }^{1,4}$, Xueshun Chen ${ }^{1}$, Qixin Tan ${ }^{1,4}$, Xiaole Pan ${ }^{1}$, \\ and Zifa Wang ${ }^{1,4,5}$ \\ ${ }^{1}$ State Key Laboratory of Atmospheric Boundary Layer Physics and Atmospheric Chemistry (LAPC), \\ Institute of Atmospheric Physics (IAP), Chinese Academy of Sciences (CAS), Beijing 100029, China \\ ${ }^{2}$ Lancaster Environment Centre, Lancaster University, Lancaster LA1 4YQ, United Kingdom \\ ${ }^{3}$ PLA 96941 Army, Beijing 102206, China \\ ${ }^{4}$ University of Chinese Academy of Sciences, Beijing 100049, China \\ ${ }^{5}$ Center for Excellence in Regional Atmospheric Environment, Institute of Urban Environment, \\ Chinese Academy of Sciences, Xiamen 361021, China \\ ${ }^{6}$ National Center for Climate Change Strategy and International Cooperation, Ministry of Ecology and Environment, \\ Beijing 100035, China
}

Correspondence: Baozhu Ge (gebz@mail.iap.ac.cn) and Zifa Wang (zifawang@mail.iap.ac.cn)

Received: 3 November 2020 - Discussion started: 27 November 2020

Revised: 18 May 2021 - Accepted: 21 May 2021 - Published: 22 June 2021

\begin{abstract}
Wet scavenging is an efficient pathway for the removal of particulate matter (PM) from the atmosphere. High levels of PM have been a major cause of air pollution in Beijing but have decreased sharply under the Air Pollution Prevention and Control Action Plan launched in 2013. In this study, 4 years of observations of wet deposition have been conducted using a sequential sampling technique to investigate the detailed variation in chemical components through each rainfall event. We find that the major ions, $\mathrm{SO}_{4}^{2-}, \mathrm{Ca}^{2+}$, $\mathrm{NO}_{3}^{-}$, and $\mathrm{NH}_{4}^{+}$, show significant decreases over the 20132017 period (decreasing by 39\%, 35\%, 12\%, and $25 \%$, respectively), revealing the impacts of the Action Plan. An improved method of estimating the below-cloud scavenging proportion based on sequential sampling is developed and implemented to estimate the contribution of below-cloud and in-cloud wet deposition over the four-year period. Overall, below-cloud scavenging plays a dominant role to the wet deposition of four major ions at the beginning of the Action Plan. The contribution of below-cloud scavenging for $\mathrm{Ca}^{2+}$, $\mathrm{SO}_{4}^{2-}$, and $\mathrm{NH}_{4}^{+}$decreases from above $50 \%$ in 2014 to below $40 \%$ in 2017. This suggests that the Action Plan has mitigated PM pollution in the surface layer and hence decreased scavenging due to the washout process. In contrast, we find little change in the annual volume weighted average concen-
\end{abstract}

tration for $\mathrm{NO}_{3}^{-}$where the contribution from below-cloud scavenging remains at $\sim 44 \%$ over the 2015-2017 period. While highlighting the importance of different wet scavenging processes, this paper presents a unique new perspective on the effects of the Action Plan and clearly identifies oxidized nitrogen species as a major target for future air pollution controls.

\section{Introduction}

Atmospheric wet deposition is a key removal pathway for air pollutants and is governed by two main processes: incloud and below-cloud scavenging (Goncalves et al., 2002; Andronache, 2003, 2004a; Henzing et al., 2006; Sportisse, 2007; Feng, 2009; Wang et al., 2010; Zhang et al., 2013). The below-cloud scavenging process depends both on the characteristics of the rain (snow), including the raindrop size distribution and rainfall rate, and on the chemical nature of the particles and their concentrations in the atmosphere (Chate et al., 2003). Previously, below-cloud scavenging was thought to be less important than in-cloud processes and was simplified or even ignored in many global and regional chemical transport models (CTMs) (Barth et al., 2000; Tang et al., 2005; 
ENVIRON.Inc, 2005; Textor et al., 2006; Bae et al., 2010). However, more recent extensive research on wet scavenging has found that precipitation, even light rain, can remove $50 \%-80 \%$ of the number or mass concentration of belowcloud aerosols, and this is supported by both field measurements and semi-empirical parameterizations of below-cloud scavenging in models (Andronache, 2004b; Zhang et al., 2004; Wang et al., 2014). Xu et al. $(2017,2019)$ studied the below-cloud scavenging mechanism based on the simultaneous measurement of aerosol components in rainfall and in the air in Beijing. They found that below-cloud scavenging coefficients for $\mathrm{PM}_{2.5}$ widely used in CTMs $\left(\sim 10^{-5}-10^{-6}\right)$ were 1-2 orders of magnitude lower than estimates from observations (at the range of $10^{-4}-10^{-5}$ for $\mathrm{SO}_{4}^{2-}, \mathrm{NO}_{3}^{-}$, and $\mathrm{NH}_{4}^{+}$.). This implies that the simulated below-cloud scavenging of aerosols might be significantly underestimated. This could be one reason for the underestimation of $\mathrm{SO}_{4}^{2-}$ and $\mathrm{NO}_{3}^{-}$wet deposition in regional models of Asia reported in phase II and III of the Model Inter-Comparison Study for Asia (MICS-Asia) (Wang et al., 2008; Itahashi et al., 2020; Ge et al., 2020) and in global model assessments by the Task Force on Hemispheric Transport of Atmospheric Pollutants (TF-HTAP) (Vet et al., 2014), in addition to the other sources of model uncertainties (Chen et al., 2019; Tan et al., 2020; Kong et al., 2020), such as emissions, chemical transformation, and changes in other ambient compounds of sulfur and nitrogen. Bae et al. (2012) added a new below-cloud scavenging parameterization scheme in the CMAQ model and improved the simulation of aerosol wet deposition fluxes in East Asia by as much as a factor of 2 compared with observations. The below-cloud scavenging process is critical not only for wet deposition but also for the concentration of aerosols in the air, and it should be represented appropriately in CTM simulations.

It is important to recognize the contribution of belowcloud scavenging to total wet deposition. However, many studies have found that it is difficult to separate the two wet scavenging processes based on measurement methods alone (Huang et al., 1995; Wang and Wang, 1996; Goncalves et al., 2002; Bertrand et al., 2008; Xu et al., 2017). A commonly used approach to separating below-cloud scavenging from total wet deposition is through sequential sampling (Aikawa et al., 2014; Ge et al., 2016; Aikawa and Hiraki, 2009; Wang et al., 2009; Quyang et al., 2015; Xu et al., 2017). In this way, precipitation composition during different stages of a rainfall event can be investigated separately in the lab after sampling. The chemical components in later increments of rainfall are thought to be less influenced by the below-cloud scavenging process than by the in-cloud scavenging process (Aikawa et al., 2014; Aikawa and Hiraki, 2009). Xu et al. (2017) applied this approach to summer rainfall in Beijing in 2014 and found that more than $50 \%$ of deposited sulfate, nitrate, and ammonium ions were from below-cloud scavenging. In this study, an innovated method based on exponential curve to chemical ions in rainfall by sequential sampling is developed and implemented to estimate the ratio of below-cloud to in-cloud wet deposition in Beijing over the four-year period between 2014 and 2017. Together with $\mathrm{PM}_{2.5}$ concentration measurements, the below-cloud scavenging effects of the decreasing air pollutants at near-surface due to the Air Pollution Prevention and Control Action Plan (Action Plan) launched in 2013 (State Council of the People's Republic of China, 2019) is also investigated to explore the implications of the Action Plain to the precipitation chemistry.

\section{Data and methods}

\subsection{Measurement site and sampling methodology}

The measurement site is located on the roof of a two-floor building at the Institute of Atmospheric Physics tower site (IAP-tower; $39^{\circ} 58^{\prime} 28^{\prime \prime} \mathrm{N}, 116^{\circ} 22^{\prime} 1^{\prime \prime} \mathrm{E}$ ) in northern Beijing. It is a typical urban site between the 3rd and 4th ring roads and lying close to the Badaling expressway (Xu et al., 2017, 2019; Sun et al., 2015). Four years of inter-annual observations of each rainfall event were conducted at this site. Sequential sampling of each rainfall event is employed to catch the evolution of precipitation composition during each event. To investigate the detailed variation in the concentration of different chemical components in precipitation, especially the sharp changes occurring during the onset of rainfall, high resolution sampling of rainfall at $1 \mathrm{~mm}$ sequential increments was performed using an automatic wet-dry sampler. The rainwater collector uses a circular polyethylene board with a $30 \mathrm{~cm}$ diameter and collects up to eight fractions. About $70 \mathrm{~mL}$ of rainwater is collected for each of the first seven fractions and the rest of the rainfall is collected in the eighth fraction. For example, if there is $12 \mathrm{~mm}$ rainfall volume in a precipitation event, $1 \mathrm{~mm}$ sequential rainfall is collected in each of the first seven fractions with the rest of $5 \mathrm{~mm}$ in the eighth fraction. Rainfall events where eight fractions are collected and identified as full events, and those with fewer than eight fractions are characterized as incomplete events. Manual sampling methods were used to collect more than eight fractions during heavy rainfall, and these are characterized as extended events. From 2014-2017, a total of 104 precipitation events, which is almost 690 precipitation samples, were collected. Of the total number of precipitation events, 33 events $(32 \%)$ were discarded from the sequential sampling analysis due to low rainfall amounts $(<8 \mathrm{~mm})$, which cannot satisfy the rules of full events. Altogether, 69 full events including six extended events were recorded over the 2014-2017 period in Beijing as 15, 16, 20, and 18 events at each year, respectively. The rainfall volume of the eighth fraction of these 69 full events varied from 1 to $55.9 \mathrm{~mm}$.

After collection, all samples are refrigerated at $0-4{ }^{\circ} \mathrm{C}$ and analysed at the Key Laboratory for Atmospheric Chemistry, Chinese Academy of Meteorological Sciences (CAMS), within one month, following the procedure used for the Acid 
Rain Monitoring Network run by the China Meteorological Administration (CMA-ARMN) (Tang et al., 2007, 2010). Nine ions that include four anions $\left(\mathrm{SO}_{2}^{4-}, \mathrm{NO}_{3}^{-}, \mathrm{Cl}^{-}\right.$and $\left.\mathrm{F}^{-}\right)$and five cations $\left(\mathrm{NH}_{4}^{+}, \mathrm{Na}^{+}, \mathrm{K}^{+}, \mathrm{Ca}^{2+}\right.$ and $\left.\mathrm{Mg}^{2+}\right)$ are detected using ion chromatography (IC, Dionex 600, USA). Their relative standard deviations in reproducibility tests are less than $5 \%$. Quality assurance is carried out using routine standard procedure of blind sample inter-comparison organized by CMA (Tang et al., 2010). Quality control is conducted by assessment of the anion-cation balance and by comparison of the calculated and measured conductivity. A more detailed description of the procedure can be found in Ge at al. (2016) and Xu et al. (2017).

\subsection{Aerosol measurements}

Aerosol mass concentration is recorded in routine measurements for the observation network of the China National Environmental Monitoring Center (CNEMC). $\mathrm{PM}_{2.5}$ concentrations are used from the Olympic Park station, a monitoring station located $3 \mathrm{~km}$ to the northeast of the IAPtower sampling site. In addition, an ambient ion monitor-ion chromatograph (AIM-IC) developed by URG Corp., Chapel Hill, NC, and Dionex Inc., Sunnyvale, CA, is used to measure $\mathrm{PM}_{2.5}$ composition at the sampling site between 2014 and 2017. This instrument includes a sample collection unit (URG 9000-D) for the collection of water-soluble gases and particles in aqueous solution and a sample analysis unit (two ion chromatographs, Dionex ICS-2000 and ICS-5000) for analysis of both anions and cations. The limit of detection of AIM-IC is $0.08 \mathrm{mg} \mathrm{m}^{-3}$ for $\mathrm{NH}^{4+}$ and $0.1 \mathrm{mg} \mathrm{m}^{-3}$ for the other ions. Aerosol mass concentrations and composition are both measured at $1 \mathrm{~h}$ time resolution. Detailed descriptions of the AIM-IC instrumentation can be found in Malaguti et al. (2015) and Markovic et al. (2012). The average concentration of aerosols in the $6 \mathrm{~h}$ before each rainfall event is calculated to reflect the air pollution conditions before the event. For comparisons, the yearly average concentration of aerosols has been calculated to represent the normal conditions.

\subsection{Estimation of below-cloud scavenging}

Previous studies have shown that the concentrations of chemical ions in precipitation decreases through the progression of a rainfall event and eventually stabilizes at low levels (Aikawa and Hiraki, 2009; Aikawa et al., 2014; Ge et al., 2016; Xu et al., 2017). The in-cloud and below-cloud scavenging contributions to total wet deposition are estimated based on the assumption that the concentrations in later increments can be attributed to scavenging by rainout only. According to (Seinfeld and Pandis, 2006), species can be incorporated into cloud and raindrops inside the raining cloud and this process determines the initial concentration of raindrops before they start falling below the cloud base. In this stage, despite the efficient process of the nucleation scavenging in cloud, the total mass of aerosol in cloud is almost stable due to the slow process of interstitial aerosol collection by cloud droplets, which is the determination process to aerosol mass. That is to say, the initial concentration of raindrops in cloud is well mixed and can be considered in a stable state during the whole rainfall event. That is why many observations in different regions (Aikawa et al., 2009, 2014; Wang et al., 2009; Quyang et al., 2015; Xu et al., 2017) reported that the chemical components in a rainfall event show a decayed variation with the increase of precipitation amount and eventually tends to a stable and low-concentration level. The assumption in this study as well as the previous studies is based on this fact. It does not mean the below-cloud and incloud scavenging occur in sequence. But, instead, the two processes have been mixed in all stages of the rainfall event with the below-cloud scavenging contributing more in beginning fraction and the in-cloud scavenging contributing more in the later fraction due to the depletion of the air pollutants below cloud by washout.

This assumption relies on the efficient scavenging of air pollutants below cloud through the evolution of precipitation. However, the concentration of chemical ions in precipitation may also be affected by many other factors in addition to below-cloud air pollutant concentrations and in-cloud scavenging processes. For example, the precipitation intensity may affect the scavenging efficiency of air pollutants below cloud and hence influence wet deposition (Andronache, 2004b; Wang et al., 2014; Xu et al., 2017, 2019). Yuan et al. (2014) reported that in central North China high intensity rainfall events of short duration (lasting less than $6 \mathrm{~h}$ ) are dominant rather than long-duration rainfall that is more common in the Yangtze River Valley. Therefore, the time window for the definition of in-cloud stage is very important for estimating the below cloud and in-cloud contributions. Previous studies have estimated the concentrations of chemical ions scavenged in-cloud based on the judgement that $5 \mathrm{~mm}$ of accumulated precipitation is sufficient to identify the contribution of the in-cloud scavenging process (Wang et al., 2009; Aikawa and Hiraki, 2009; Xu et al., 2017). Based on this approach, the concentrations of $\mathrm{NO}_{3}^{-}$and $\mathrm{SO}_{4}^{2-}$ in cloud in Japan were found to be 0.70 and $1.30 \mathrm{mg} \mathrm{L}^{-1}$, respectively (Aikawa and Hiraki, 2009). In Beijing, high concentrations of $\mathrm{NH}_{4}^{+}, \mathrm{SO}_{4}^{2-}$, and $\mathrm{NO}_{3}^{-}$in 2007 were found at 2.1-5.5, 3.114.9, and 1.5-5.9 $\mathrm{mg} \mathrm{L}^{-1}$, respectively (Wang et al., 2009; Xu et al., 2017).

In this study, a new method based on fitting a curve to the chemical ion concentrations with successive rainfall increments has been developed to estimate the contribution of the in-cloud process. As shown in Fig. 1, an exponential curve is fitted to the median, 25th, and 75th percentiles of the chemical ion concentrations in each fraction through the rainfall increments. Note that the fitted exponential curve is applied to the combination of all 69 full events to estimate the yearly median concentration of chemical ions in-cloud and to com- 
pare with the results from the previously reported method (i.e. median concentration after $5 \mathrm{~mm}$ increments). In addition, the exponential approach to each unique event was also employed. Ideally, the concentrations of chemical ions stabilize at higher rainfall increments and this represents the concentrations in cloud. However, the decrease during each rainfall event is distinctly different, and this regression method is not fully applicable to all rainfall events in practice. Therefore, the exponential regression method is used to estimate the in-cloud concentrations under most circumstances, but where the decreasing trend with the increment of rainfall is not significant, the average value of rainfall increments $6-8$ of the event is used. The below-cloud contributions to wet deposition of each species are then calculated using the following equations (Eqs. 1-2):

Wetdep $_{\text {below-cloud }}=\sum_{i=1}^{n}\left(C_{i}-\bar{C}\right) \times P_{i}$

Contribution $_{\text {below-cloud }}=\frac{\text { Wetdep }_{\text {below-cloud }}}{\sum_{i=1}^{n} C_{i} \times P_{i}}$,

where $C_{i}$ and $\bar{C}$ represent the concentration of each chemical ion in fraction $i$ in cloud, $P_{i}$ represents the volume of rainfall, and $n$ represent the total fractions in a rainfall event (equal to 8 in this study).

\section{Results and discussion}

\subsection{Inter-annual variations in chemical components}

The Action Plan launched in 2013 is called "Ten rules" to improve the air quality in China. It includes the comprehensive control of industrial emissions, non-point emissions, fugitive dust, and vehicles emissions. It is also aimed at adjusting and optimizing the industrial structure and promoting economic transformation and upgrading, such as increasing the supply of clean energy. These actions are ensured to work by both of legislation and market mechanisms. According to the Beijing Environmental Statement published by the Beijing Municipal Environmental Protection Bureau from 2013 to 2017, many measures have been implemented to meet the Action Plan, including replacement of residential coal with electricity and natural gas, upgrading the emission standards of gasoline, diesel vehicles, and power plants, and closing high-emission enterprises. Significant declines in atmospheric $\mathrm{PM}_{2.5}$ concentration have been observed nationwide between 2013 and 2017 during the Action Plan (Zhang et al., 2019). However, few studies have investigated the benefits of the Action Plan for wet deposition. A significant increase of $\mathrm{NO}_{3}^{-}$in precipitation of $7.6 \%$ was observed at a regional background station in North China between 2003 and 2014 (Pu et al., 2017). A decrease in the ratio of $\mathrm{SO}_{4}^{2-} / \mathrm{NO}_{3}^{-}$, mostly due to the decreasing of $\mathrm{SO}_{4}^{2-}$ and increasing of $\mathrm{NO}_{3}^{-}$, suggests the transformation of a sulfuric acid type to a mixed type of sulfuric and nitric acid in
North China. However, the updated record especially after the Action Plan is important to assess the mitigation of the air pollutants not only in the atmosphere but also in rainfall. A nationwide investigation of the wet deposition of inorganic ions in 320 cities across China was recently made based on observations between 2011 and 2016 from the National Acid Deposition Monitoring Network (NADMN), which was established by the China Meteorological Administration ( $\mathrm{Li}$ et al., 2019). Briefly, both $\mathrm{SO}_{4}^{2-}$ and $\mathrm{NO}_{3}^{-}$across China experienced significant changes before and after 2014, with increases from 2011 to 2014 and then decreases from 2014 to 2016.

In order to quantify the influence of the Action Plan on wet deposition in Beijing, 4 years of observations of each rainfall event are considered in this study. Figure 2 shows the volume weighted average (VWA) of inter-annual mean concentrations of $\mathrm{SO}_{4}^{2-}, \mathrm{NO}_{3}^{-}, \mathrm{NH}_{4}^{+}$, and $\mathrm{Ca}^{2+}$ observed in Beijing from 2014 to 2017 along with those reported before 2010 from previous studies (Yang et al., 2012; Pan et al., 2012, 2013) (more detail is provided in Table S1 in the Supplement). A continuous decrease in VWA concentrations between 1995 and 2017 is found for $\mathrm{SO}_{4}^{2-}$, with decreases of $3.1 \% \mathrm{yr}^{-1}$ in the earlier stage (1995-2010) and decreases of $9.8 \% \mathrm{yr}^{-1}$ in the later stage (2014-2017). This is consistent with the annual changes in its emission and concentration as shown in Fig. 3, in which the emission and the concentration data are collected from the annual Environmental Bulletin in Beijing from 1994 to 2017. It is clearly shown that the concentration of $\mathrm{SO}_{2}$ experienced a sustainably decreasing trend due to significant reduction of its emission from 1996 to 2017, with the decrease rate being $4.5 \% \mathrm{yr}^{-1}$ and $13.9 \% \mathrm{yr}^{-1}$ in emission and $2.8 \% \mathrm{yr}^{-1}$ and $14.0 \% \mathrm{yr}^{-1}$ in concentration during the earlier stage and later stage (of the Action Plan period), respectively. The significant declines in VWA concentration of $\mathrm{Ca}^{2+}$ is found in precipitation with decrease rates of $36.1 \% \mathrm{yr}^{-1}$ in 1995-2010 and $8.8 \% \mathrm{yr}^{-1}$ in $2014-2017$. The emission and concentration data of $\mathrm{Ca}^{2+}$ are absent in this study. Instead, the difference between the $\mathrm{PM}_{10}$ and $\mathrm{PM}_{2.5}\left(\mathrm{PM}_{10}-\mathrm{PM}_{2.5}\right)$ concentration from 2013-2017 have been calculated to represent the coarse particles, which mainly contain $\mathrm{Ca}^{2+}$. The results show that the concentration decreased from $31.2 \mu \mathrm{g} \mathrm{m}^{-3}$ in 2013-2014 to $24.0 \mu \mathrm{g} \mathrm{m}^{-3}$ over $2015-2017$. This indicates the improvement in coarse particles, which are derived from crustal emissions, that has been made through the Action Plan. As mentioned above, the Action Plan including emission reduction is not only from the energy consumption of industry but also the fugitive dust in cities, which should result in the decline of $\mathrm{Ca}^{2+}$. For $\mathrm{NO}_{3}^{-}$and $\mathrm{NH}_{4}^{+}$, increases are found during the earlier stage $(\sim 60 \%)$ and decreases in the later stage $\left(12 \%\right.$ for $\mathrm{NO}_{3}^{-}$and $25 \%$ for $\mathrm{NH}_{4}^{+}$). As for $\mathrm{NO}_{x}$ emissions, data have been collected in recent years. Although a clear reduction is found in the annual changes in emissions from 2010, the ambient concentration of $\mathrm{NO}_{2}$ do not show a significant decreasing trend $\left(\sim 3.6 \% \mathrm{yr}^{-1}\right)$ compared with $\mathrm{SO}_{2}$ 

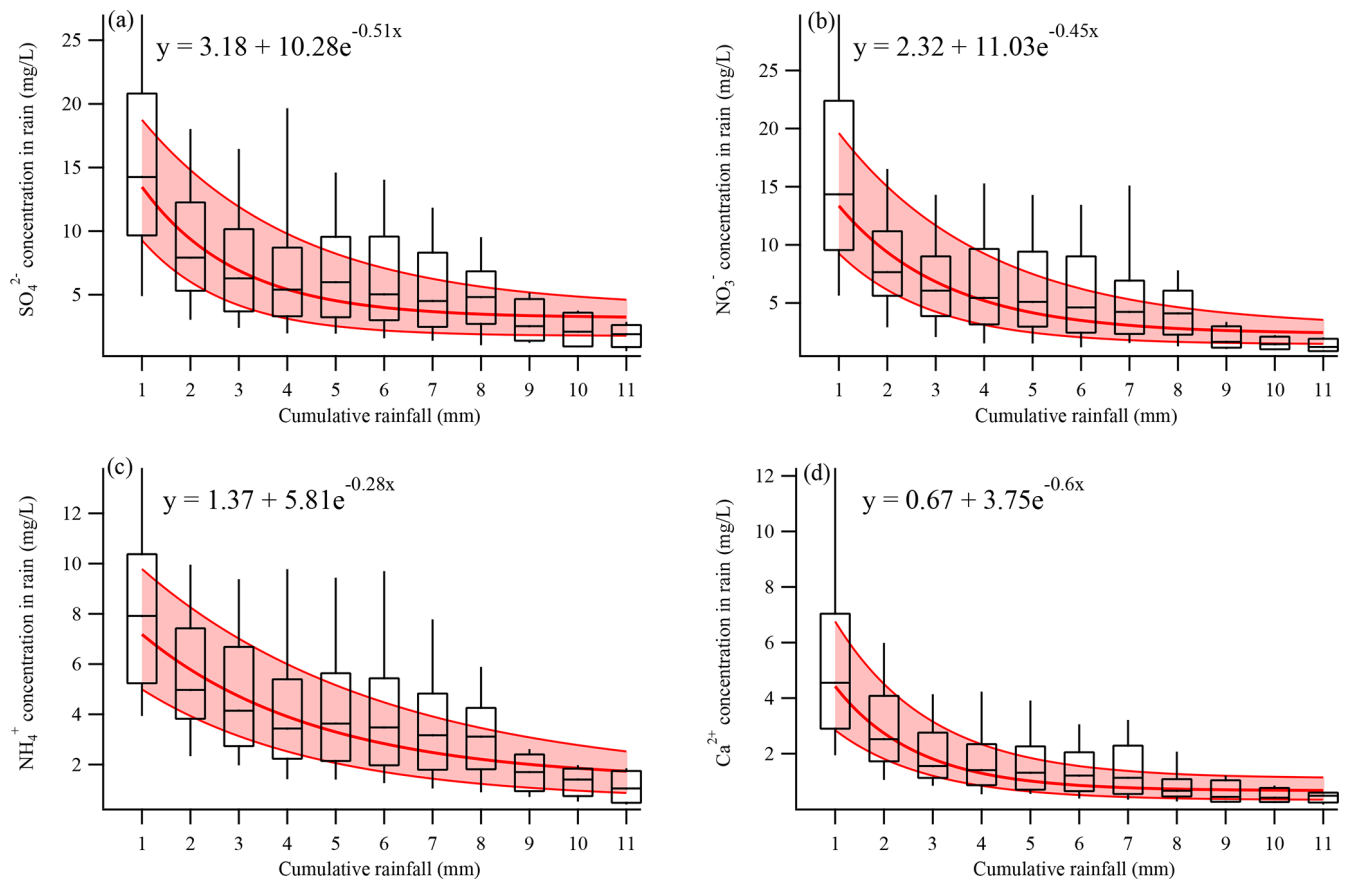

Figure 1. Concentrations of $\mathrm{SO}_{4}^{2-}(\mathbf{a}), \mathrm{NO}_{3}^{-}(\mathbf{b}), \mathrm{NH}_{4}^{+}$(c), and $\mathrm{Ca}^{2+}$ (d) in each $1 \mathrm{~mm}$ fraction of rainfall (i.e. F1\#, F2\#, ...) over different rainfall events in the observation periods. The red line shows an exponential fitting using the 50th percentile of the data and the red shading indicates the range between the 25 th and 75 th percentiles.

$\left(14 \% \mathrm{yr}^{-1}\right)$. However, before the Action Plan, the decreasing ratio in concentration was only $1.8 \% \mathrm{yr}^{-1}$, which is slower than the Action Plan period. Despite the increases of VWA $\mathrm{NO}_{3}^{-}$in precipitation during the earlier stage, the small decreases in the later stage could also be attributable to the Action Plan.

For a better understanding of the impacts of acidification on ecosystems, wet deposition fluxes of the four major ions in precipitation are also plotted in Fig. 2. Similar variations are found as those presented in the VWA of the four major ions. Observations of sulfur and nitrogen wet deposition (Pan et al., 2012, 2013) from 2007-2010 show the value of $21.5 \mathrm{~kg} \mathrm{Sha}^{-1} \mathrm{yr}^{-1}$ and $27.9 \mathrm{~kg} \mathrm{Nha}^{-1} \mathrm{yr}^{-1}(19.7$ and $8.2 \mathrm{~kg} \mathrm{Nha}^{-1} \mathrm{yr}^{-1}$ through $\mathrm{NO}_{3}^{-}$and $\mathrm{NH}_{4}^{+}$) in Beijing, respectively. Compared with these results, significant decreases (11.4 $\mathrm{kg} \mathrm{Sha}^{-1} \mathrm{yr}^{-1}$ and $23.6 \mathrm{~kg} \mathrm{~N} \mathrm{ha}^{-1} \mathrm{yr}^{-1}$ ) were observed in the 4 years of measurements from 2014-2017 in this study. All four components in the later stage show significant decreases, suggesting that the Action Plan, which was implemented over this period, has a substantial impact. While $\mathrm{Ca}^{2+}$ and $\mathrm{SO}_{4}^{2-}$ played a prominent role in precipitation during the earlier stage before $2010, \mathrm{NH}_{4}^{+}$and $\mathrm{NO}_{3}^{-}$ became the primary components in the later stage after 2010 . It should be noted that $\mathrm{NH}_{4}^{+}$has a double role in environmental pollution because it mitigates acid rain through neutralization, but also acidifies the soil by nitrification. Hence, while sulfur in precipitation has been further reduced under the Action Plan, additional attention is needed for nitrogen to prevent deterioration of the environment by acid rain resulting from nitrate and ammonium.

\subsection{Relationship between concentration in precipitation and the atmosphere}

Wet deposition of a substance involves its removal from the associated air mass. The scavenging ratio $H$ can be estimated by comparing the monthly average concentration in precipitation with that in the air (Okita et al., 1996; KasperGiebl et al., 1999; Hicks, 2005; Yamagata et al., 2009). Xu et al. (2017) first calculated the rainfall event $H$ based on the hourly concentration of aerosol components measured with an Aerodyne Aerosol Chemical Speciation Monitor (ACSM) and AIM-IC in 2014. In this study, 4 years of aerosol component observations were undertaken by AIM-IC. Measurements made in the $6 \mathrm{~h}$ before each rainfall event are averaged to represent the precondition of wet deposition precursors in the atmosphere. Figure 4 shows the relationship between the major chemical ions in precipitation and in the air. The VWA concentration of $\mathrm{SO}_{4}^{2-}, \mathrm{NO}_{3}^{-}$, and $\mathrm{NH}_{4}^{+}$(hereafter SNA) as well as $\mathrm{Ca}^{2+}$ in each rainfall event was calculated and compared with that in the first $1 \mathrm{~mm}$ rainfall fraction, F1\#. As shown in Fig. 4, positive correlations are found between the concentrations of ions in precipitation and in air, with Pearson correlation coefficients $(R)$ generally higher than $0.7(p<0.01)$. The concentration in the first fraction represents a high proportion of below-cloud scavenging due 

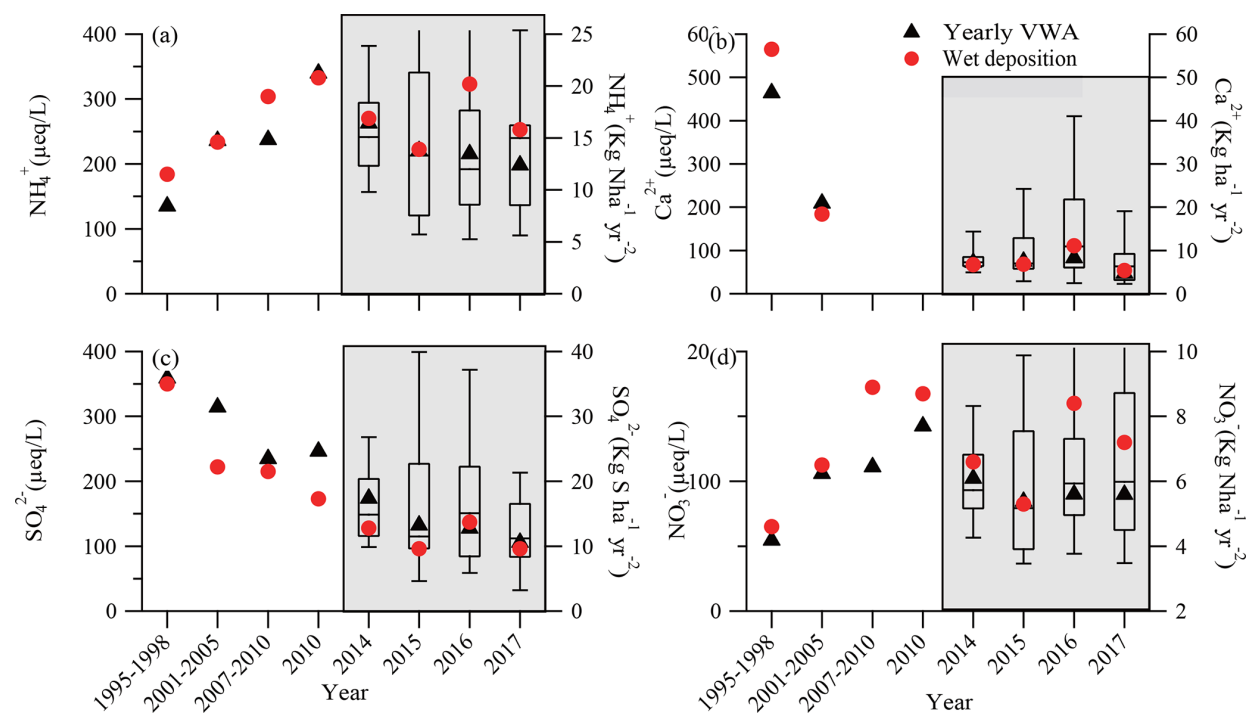

Figure 2. Time series of annual volume weighted average (VWA) concentration and wet deposition of the four major components $\mathrm{NH}_{4}^{+}$(a), $\mathrm{Ca}^{2+}(\mathbf{b}), \mathrm{SO}_{4}^{2-}(\mathbf{c})$, and $\mathrm{NO}_{3}^{-}(\mathbf{d})$ in precipitation in Beijing.

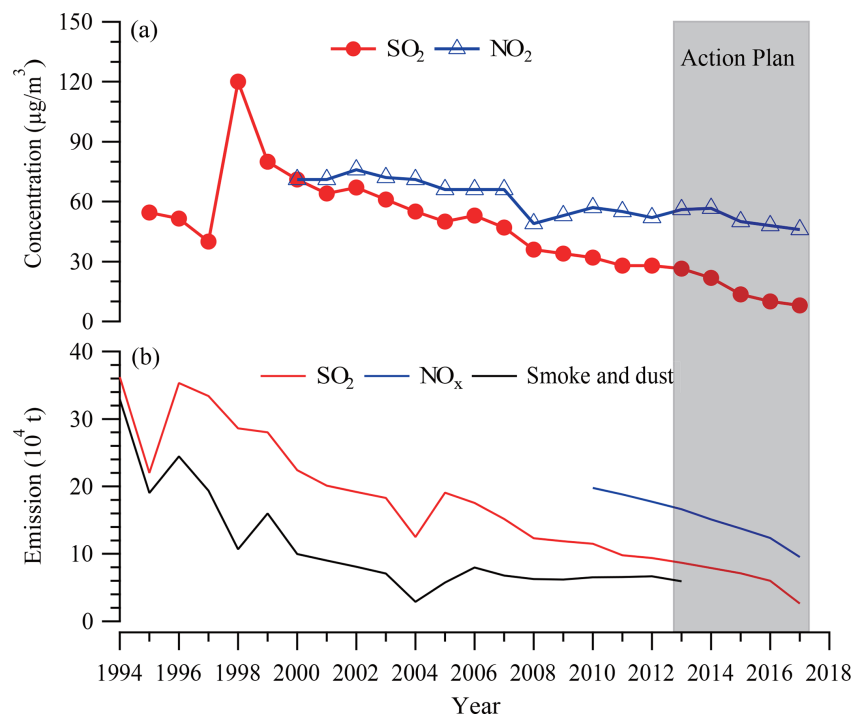

Figure 3. Annual changes in emission and concentration of $\mathrm{SO}_{2}$ and $\mathrm{NO}_{x}$ in Beijing; data are collected from the annual Environmental Bulletin in Beijing from 1994 to 2017.

to the washout of air pollutants below cloud by the first rainfall, while the VWA represents a greater contribution from in-cloud removal (Aikawa and Hiraki, 2009; Wang et al., 2009; Xu et al., 2017). Thus, it is reasonable that the correlations are stronger for the first fraction than for the VWA (see Table 1). This indicates that the concentration of chemical ions in precipitation at the start of rainfall is more greatly influenced by the air pollutants below the cloud. As rainfall continues and below-cloud concentrations are reduced, there is an increased contribution from in-cloud scavenging, which is less influenced by aerosols in the surface layer. This is confirmed by the substantial difference in the two $R$ coefficients for the cation $\mathrm{Ca}^{2+}$ ( 0.85 for the first fraction, 0.47 for the VWA), which often exists in coarse particles below cloud. For the fine particle $\mathrm{SO}_{4}^{2-}$, which is present both in and below cloud (Xu et al., 2017), the difference in the two $R$ coefficients is small. The $R$ coefficients for $\mathrm{NO}_{3}^{-}$and $\mathrm{NH}_{4}^{+}$show less difference than $\mathrm{Ca}^{2+}$ but more difference than $\mathrm{SO}_{4}^{2-}$. This may relate to their complicate sources from the ambient precursors. For example, the $\mathrm{NO}_{3}^{-}$in precipitation is both from the fine and coarse particles (i.e. particulate $\mathrm{NO}_{3}^{-}$) as well as the gaseous $\mathrm{HNO}_{3}$, while the $\mathrm{NH}_{4}^{+}$in precipitation is mainly from the fine particles in addition to $\mathrm{NH}_{3}$.

The slope of the linear fits in Fig. 4 can be used to calculate the scavenging ratio $W$, which is the ratio of the ions concentration in precipitation $\left(\mathrm{mg} \mathrm{L}^{-1}\right)$ and in air $\left(\mu \mathrm{g} \mathrm{m}^{-3}\right)$. The $W$ ratio is $0.25 \times 10^{6}, 0.16 \times 10^{6}$, and $0.15 \times 10^{6}$ for $\mathrm{SO}_{4}^{2-}, \mathrm{NO}_{3}^{-}$, and $\mathrm{NH}_{4}^{+}$, respectively. This is similar to that reported for rainfall events in 2014 in Beijing $\left(0.26 \times 10^{6}\right.$, $0.35 \times 10^{6}$, and $0.14 \times 10^{6}$ for SNA; Xu et al. (2017)) and consistent with those estimated in the eastern United States $\left(0.11-0.38 \times 10^{6}, 0.38-0.97 \times 10^{6}\right.$, and $0.2-0.75 \times 10^{6}$ for SNA; (Hicks, 2005)). Compared with $\mathrm{SO}_{4}^{2-}$ and $\mathrm{NH}_{4}^{+}$, the scavenging ratio for $\mathrm{NO}_{3}^{-}$shows larger differences between this study and previous studies, corresponding to larger uncertainties to the $R$ between the concentrations of ions in precipitation and in air for VWA in Fig. 4a (lower significance $p<0.05)$. It should be noted that the $W$ calculated in this study is based on the fine particles in air, which may not represent the accurate reflection of the wet scavenging efficiency of SNA. These uncertainties have been evaluated. For sulfur, gaseous $\mathrm{SO}_{2}$ was considered to testify its role in the relation- 
Table 1. Correlation of the concentrations of major ions in air in the $6 \mathrm{~h}$ before rainfall with those in precipitation. Pearson correlation coefficients are presented for monthly volume weighted average (VWA) concentrations and for the first fraction $\left(\mathrm{F} 1^{\#}\right)$ in each event.

\begin{tabular}{lrrrr}
\hline & $\mathrm{SO}_{4}^{2-}(n=13)$ & $\mathrm{NO}_{3}^{-}(n=14)$ & $\mathrm{NH}_{4}^{+}(n=13)$ & $\mathrm{Ca}^{2+}(n=9)$ \\
\hline $\mathrm{VWA}$ & $0.70^{*}$ & $0.53^{* *}$ & $0.65^{*}$ & 0.47 \\
$\mathrm{Fi}^{\#}$ & $0.76^{*}$ & $0.62^{*}$ & $0.77^{*}$ & $0.85^{*}$ \\
\hline
\end{tabular}

Note: ${ }^{*}$ and ${ }^{* *}$ represent significant correlations at $p<0.01$ and $p<0.05$, respectively.
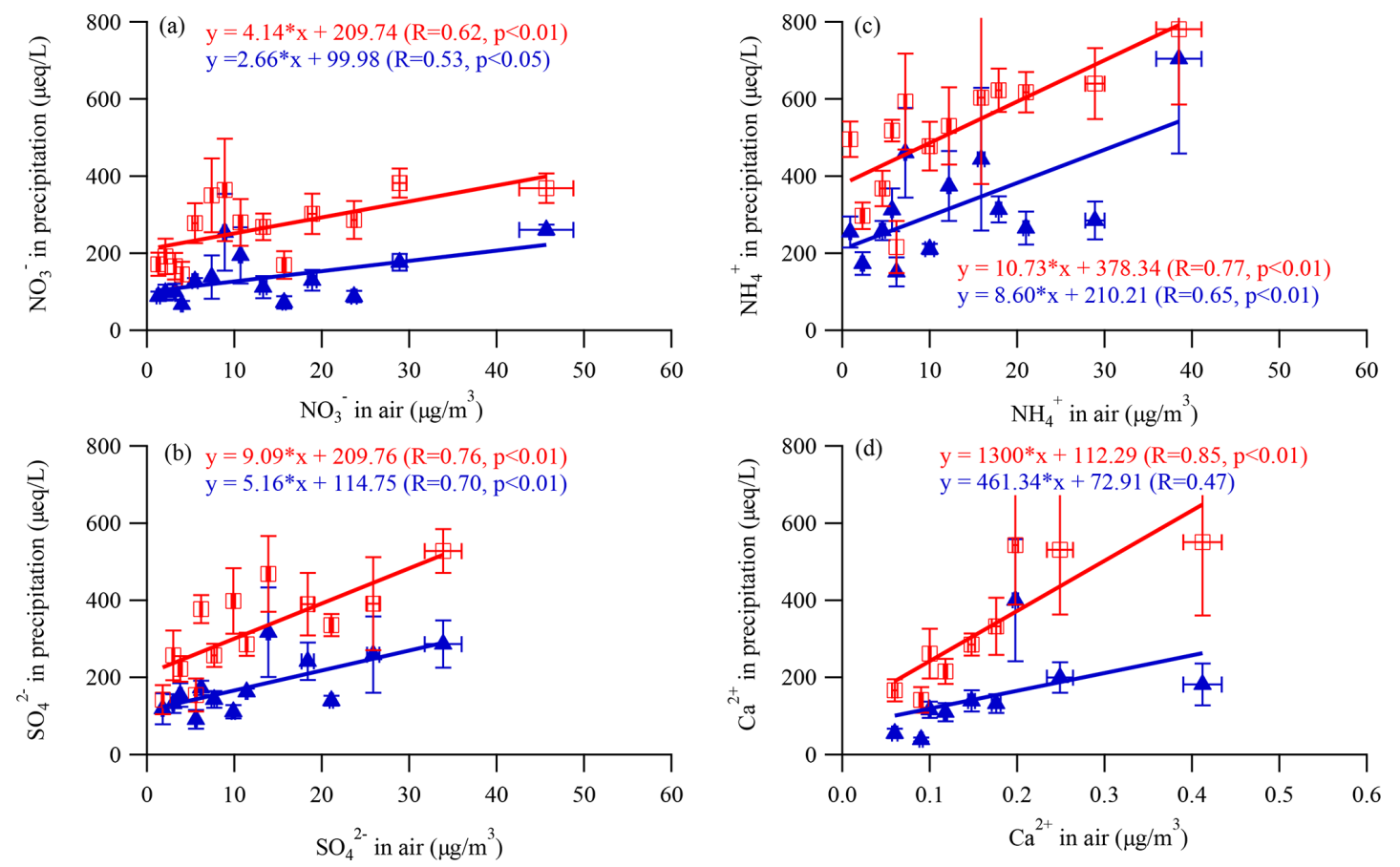

Figure 4. Relationships between the concentration of $\mathrm{NO}_{3}^{-}(\mathbf{a}), \mathrm{SO}_{4}^{2-}(\mathbf{b}), \mathrm{NH}_{4}^{+}(\mathbf{c})$, and $\mathrm{Ca}^{2+}$ (d) in precipitation and in air in the $6 \mathrm{~h}$ before each precipitation event. The red squares and blue triangles represent the relationships between the concentration of ions in air with that in F1\# and VWA, respectively.

ships. Figure S1 in the Supplement shows the relationships between the concentration of $\mathrm{SO}_{4}^{2-}$ in precipitation and in air $\left(\mathrm{SO}_{4}^{2-}\right.$ in precipitation vs. $\mathrm{SO}_{4}^{2-}$ and $\mathrm{SO}_{4}^{2-}$ in precipitation vs. $\mathrm{SO}_{2}+\mathrm{SO}_{4}^{2-}$ ). The correlation coefficients $R$ increased if the role of gaseous $\mathrm{SO}_{2}$ was considered (the $R$ of $\mathrm{SO}_{4}^{2-}$ in precipitation vs. $\mathrm{SO}_{4}^{2-}$ is 0.7 and the $R$ of $\mathrm{SO}_{4}^{2-}$ in precipitation vs. $\mathrm{SO}_{2}+\mathrm{SO}_{4}^{2-}$ is 0.75 ). However, the scavenging ratio $W$ was not changed, with the difference being lower that $1 \%$. For nitrogen, the contribution of gaseous $\mathrm{HNO}_{3}$ to total inorganic nitrate is less than $2 \%$ in the North China Plain according to Zhai et al. (2021), which can be ignored in this study. According to more than one year of measurements in Beijing (Tian et al., 2016), $\mathrm{SO}_{4}^{2-}, \mathrm{NO}_{3}^{-}$, and $\mathrm{NH}_{4}^{+}$in coarse particles account for $18 \%, 27 \%$, and $10 \%$, respectively. The lower $R$ coefficient for $\mathrm{NO}_{3}^{-}$than for $\mathrm{SO}_{4}^{2-}$ and $\mathrm{NH}_{4}^{+}$in Fig. 4 is attributed to the absence of considering $\mathrm{NO}_{3}^{-}$in coarse particles. In addition, due to high concentration of $\mathrm{NH}_{3}$ at ground surface over NCP (Pan et al., 2018), the $\mathrm{NH}_{4}^{+}$in precipita- tion from gaseous $\mathrm{NH}_{3}$ cannot be ignored (Kasper-Giebl et al., 1999). The ratio of $\mathrm{NH}_{4}^{+} /\left(2 \mathrm{SO}_{4}^{2-}+\mathrm{NO}_{3}^{-}\right)$in precipitation and in $\mathrm{PM}_{2.5}$ was calculated. A lower ratio in precipitation than in $\mathrm{PM}_{2.5}$ was found, with $0.95-1.01$ in precipitation and 1.35 in air. This is due to the impacts of rich gaseous $\mathrm{NH}_{3}$ at ground surface going into the precipitation by reacting with gaseous $\mathrm{HNO}_{3}$ and forming $\mathrm{NH}_{4} \mathrm{NO}_{3}$ after $\left(\mathrm{NH}_{4}\right)_{2} \mathrm{SO}_{4}$. Thus, the contribution of coarse particles and gases to the relationships between sulfur and nitrogen compounds in precipitation and the atmosphere is not as important as the fine particles, except for $\mathrm{NO}_{3}^{-}$in coarse particles and gaseous $\mathrm{NH}_{3}$, which should be considered in the future.

Wet deposition can affect much of the atmospheric column through in-cloud and below-cloud scavenging processes. The vertical column density (VCD) of $\mathrm{SO}_{2}$ and $\mathrm{NO}_{2}$ from satellite retrieval from the 2000s to 2017 is used here to compare with the inter-annual variations in wet deposition in Beijing (Fig. S2 in the Supplement). Consistent variation of the VCD 
and the yearly VWA concentration in precipitation is found for sulfur and nitrogen. A continuous decrease is found in VCD SO 2 from 2005 to 2017, matching the trend in $\mathrm{SO}_{4}^{2-}$ deposition, while $\mathrm{VCD} \mathrm{NO} \mathrm{N}_{2}$ shows an increase from 2001 to 2011, a decrease after 2011, and little change over the 20142017 period. This implies that the Action Plan not only benefits air pollutants in the surface layer but also those in the total column. Due to faster decreases in emissions of sulfur than nitrogen (Zheng et al., 2018), the ratio of $\mathrm{S} / \mathrm{N}$ in both precipitation $\left(\mathrm{SO}_{4}^{2-} / \mathrm{NO}_{3}^{-}\right.$, $\mu$ eq. $\left.\mathrm{L}^{-1}\right)$ and air $\left(\mathrm{SO}_{4}^{2-} / \mathrm{NO}_{3}^{-}, \mu \mathrm{g} \mathrm{m}^{-3}\right)$ are found to decrease, with the change in ratio in precipitation at $17.5 \% \mathrm{yr}^{-1}, 11 \% \mathrm{yr}^{-1}$, and $20.0 \% \mathrm{yr}^{-1}$ from $1995-$ 2010, 2014-2017, and 1995-2017, and in air at $12 \% \mathrm{yr}^{-1}$ from 2014-2017, respectively (see Fig. S3 in the Supplement). This is also consistent with the trend reported for all of China from 2000-2015 by Itahashi et al. (2018). The ratio of $\mathrm{S} / \mathrm{N}$ in precipitation is a useful index to investigate the relative contributions of these acidifying species. In addition, the ratio of $\mathrm{NH}_{4}^{+} / \mathrm{NO}_{3}^{-}$is investigated here and a clear decrease is found from 2014-2017 both in precipitation and in air. This indicates that $\mathrm{NH}_{4}^{+}$is decreasing faster than $\mathrm{NO}_{3}^{-}$. This evidence clearly confirms that nitrate should be the major target for air pollution controls in the next action plan.

\subsection{Proportion of below-cloud scavenging}

As described in Sect. 2.3, the in-cloud ion concentration $(\bar{C}$, in Eq. 1) can be derived from the exponential fit of the observed rainwater concentrations. Table 2 lists the asymptote value and the exponential fitting equation of the evolution of each ion concentration in precipitation with the increment of rainfall. As shown, the asymptote value (hereafter, exponential approach) based on the median data for $\mathrm{SO}_{4}^{2-}$, $\mathrm{NO}_{3}^{-}$, and $\mathrm{NH}_{4}^{+}$was $3.18,2.32$, and $1.39 \mathrm{mg} \mathrm{L}^{-1}$, respectively. The $\mathrm{SO}_{4}^{2-}$ and $\mathrm{NO}_{3}^{-}$are within the range of reported in-cloud concentrations for Beijing (3.33 and $2.75 \mathrm{mg} \mathrm{L}^{-1}$ for $\mathrm{SO}_{4}^{2-}$ and $\mathrm{NO}_{3}^{-}$; $\mathrm{Xu}$ et al., 2017), while the $\mathrm{NH}_{4}^{+}$in this study is lower than previous studies $\left(2.51 \mathrm{mg} \mathrm{L}^{-1}\right.$ in Xu et al., 2017 and $2.1-4.5 \mathrm{mg} \mathrm{L}^{-1}$ in Wang et al., 2009). In-cloud concentrations for other ions, i.e. $\mathrm{Ca}^{2+}, \mathrm{F}^{-}, \mathrm{Cl}^{-}, \mathrm{Na}^{+}, \mathrm{K}^{+}$, and $\mathrm{Mg}^{2+}$, are $0.67,0.04,0.27,0.1,0.06$, and $0.08 \mathrm{mg} \mathrm{L}^{-1}$, respectively. For comparison, the average concentration in fractions 6 to 8 (F6\#-F8\#) in each rainfall event (hereafter, average approach) is used to estimate the in-cloud concentration for events where successive rainwater concentrations do not show an obvious decrease or where other factors such as precipitation intensity are important (see Table 2). Similar results are found for most ions with the exponential and average approach except for $\mathrm{NH}_{4}^{+}, \mathrm{F}^{-}, \mathrm{K}^{+}$, and $\mathrm{Mg}^{2+}$, where the maximum difference is less than $20 \%$ (Table 2). Thus, the replacement of in-cloud concentration by the average value is acceptable for $\mathrm{SO}_{4}^{2-}, \mathrm{NO}_{3}^{-}, \mathrm{Ca}^{2+}, \mathrm{Cl}^{-}$, and $\mathrm{Na}^{+}$but there is much uncertainty for the other ions. It is worth noting that for all ions the average approach gives higher estimates of in-cloud concentrations, and this can be recognized as an upper limit for in-cloud concentrations. It is also important to note that the increased concentrations of ions in the latter fractions were observed in few events in this study. This may due to the unique meteorological conditions and air pollutants movement during each precipitation event. Despite the longer precipitation fractions collected in this study, even longer fraction measurements and more detailed analysis on the uncertainties are needed in the future. The influences of meteorological conditions (i.e. rainfall type and intensity) are discussed in Sect. 4.

The model study in Japan showed consistent fractions of in-cloud and below-cloud scavenging to total wet deposition between simulated and observed values, except for one site, which is the region of high emission flux of $\mathrm{SO}_{2}$. In this region, the simulated below-cloud scavenging contribution was apparently greater than the observed results. Specifically, the model shows that the $\mathrm{SO}_{2}$ and $\mathrm{HNO}_{3}$ gases dominantly contributed to the below-cloud scavenging of $\mathrm{SO}_{4}^{2-}$ and $\mathrm{NO}_{3}^{-}$in the regions of high emission flux of $\mathrm{SO}_{2}$, while the aerosol removal was dominated by the in-cloud scavenging process. In their model setup, all of below-cloud gaseous $\mathrm{SO}_{2}$ was assumed to be dissolved into raindrops and fully oxidized to $\mathrm{SO}_{4}^{2-}$. However, as suggested by Seinfeld and Pandis (2006), the aqueous equilibrium between ambient gas and precipitation cannot be assumed due to the relatively short residence times of falling precipitation. Thus, the assumptions used in Kajino and Aikawa (2015) might overestimate the contribution of gaseous $\mathrm{SO}_{2}$ to below-cloud scavenging. In addition, considering the high concentration of particles $\left(60-90 \mu \mathrm{g} \mathrm{m}^{-3}\right.$ in mass concentration) below-cloud in Beijing, the gaseous compounds may not be as important as in the Japan simulation. According to the Environmental Bulletin in Beijing from 1994 to 2017, the annual concentration of $\mathrm{SO}_{2}$ has dramatically decreased from $26.5 \mu \mathrm{g} \mathrm{m}^{-3}$ in 2013 to $8 \mu \mathrm{g} \mathrm{m}^{-3}$ in 2017 . This relatively low-level concentration of $\mathrm{SO}_{2}$ at the surface may not contribute a dominant role in wet deposition of $\mathrm{SO}_{4}^{2-}$. Similarly for $\mathrm{NO}_{3}^{-}$, the ratio of gas-phase $\mathrm{HNO}_{3}$ and the total $\mathrm{NO}_{3}^{-}$in the summer in Beijing is only 0.12 according to the measurement study of Yue et al. (2013). The fraction of total inorganic nitrate as particulate nitrate instead of gaseous nitric acid over the NCP increased from $90 \%$ in 2013 to $98 \%$ in 2017 (Zhai et al., 2021), which means the gaseous nitric acid has been consumed by high levels of ammonia concentrations. We assumed a $10 \%$ ratio of gases added into the washout process, which only leads to less than $5 \%$ difference of below-cloud scavenging contribution to total wet depositions. Regardless, there might be larger uncertainties for $\mathrm{NH}_{3}$ due to the high concentration of $\mathrm{NH}_{3}$ at ground surface over NCP (Pan et al., 2018). Kasper-Giebl et al. (1999) reported that $49 \%-$ $79 \%$ of $\mathrm{NH}_{4}^{+}$in precipitation is from particulate ammonium, which indicates that large uncertainties in the contributions from gases still exist in the form of $\mathrm{NH}_{4}^{+}$wet deposition. The uncertainties are mainly from the indistinct window for the in-cloud scavenging judgement due to high concentra- 
Table 2. Exponential fitting for the concentrations of major ions in different fractions of rainfall and the contribution of below-cloud scavenging to total deposition.

\begin{tabular}{|c|c|c|c|c|c|c|c|c|}
\hline $\begin{array}{l}\text { Chemical } \\
\text { components }\end{array}$ & $\begin{array}{l}\text { Exponential fitting for } \\
\text { 50th percentile }\end{array}$ & $\begin{array}{r}R^{2} \\
(n=11)\end{array}$ & $\begin{array}{r}\text { Asymptote value } \\
\left(\mathrm{mg} \mathrm{L}^{-1}\right)\end{array}$ & $\begin{array}{r}\text { Below cloud } \\
\%^{\mathrm{b}}\end{array}$ & $\begin{array}{r}\text { Average of } \\
\text { F6\#-F8\# }\left(\mathrm{mg} \mathrm{L}^{-1}\right)\end{array}$ & $\begin{array}{r}\text { Below cloud } \\
\%^{\mathrm{c}}\end{array}$ & $\begin{array}{r}\text { Difference } \\
\%^{\mathrm{d}}\end{array}$ & $\begin{array}{r}\text { Total wet deposition } \\
\left(\mathrm{mg} \mathrm{m}^{-2} \mathrm{yr}^{-1}\right)\end{array}$ \\
\hline $\mathrm{SO}_{4}^{2-}$ & $y=3.17+10.28 e^{-0.51 x}$ & 0.85 & 3.18 & $50 \%$ & 3.33 & $48 \%$ & $<3 \%$ & 3423.3 \\
\hline $\mathrm{NO}_{3}^{-}$ & $y=2.32+11.03 e^{-0.45 x}$ & 0.81 & 2.32 & $59 \%$ & 2.59 & $54 \%$ & $<6 \%$ & 3046.5 \\
\hline $\mathrm{NH}_{4}^{+3}$ & $y=1.39+5.81 e^{-0.28 x}$ & 0.79 & 1.39 & $65 \%$ & 1.95 & $51 \%$ & $<9 \%$ & 2149.5 \\
\hline $\mathrm{Ca}^{2+}$ & $y=0.67+6.81 e^{-0.6 x}$ & 0.93 & 0.67 & $52 \%$ & 0.72 & $48 \%$ & $<6 \%$ & 746.0 \\
\hline $\mathrm{F}^{-}$ & $y=0.04+0.24 e^{-0.34 x}$ & 0.91 & 0.04 & $56 \%$ & 0.05 & $40 \%$ & $<10 \%$ & 49.0 \\
\hline $\mathrm{Cl}^{-}$ & $y=0.27+2.2 e^{-0.6 x}$ & 0.95 & 0.27 & $53 \%$ & 0.29 & $50 \%$ & $<5 \%$ & 309.7 \\
\hline $\mathrm{Na}^{+}$ & $y=0.1+1.34 e^{-0.94 x}$ & 0.91 & 0.10 & $64 \%$ & 0.10 & $64 \%$ & $<1 \%$ & 150.6 \\
\hline $\mathrm{K}^{+}$ & $y=0.06+0.49 e^{-0.47 x}$ & 0.89 & 0.06 & $64 \%$ & 0.07 & $58 \%$ & $<9 \%$ & 89.8 \\
\hline $\mathrm{Mg}^{2+}$ & $y=0.08+0.81 e^{-0.4 x}$ & 0.83 & 0.08 & $61 \%$ & 0.11 & $46 \%$ & $<13 \%$ & 109.2 \\
\hline
\end{tabular}

tion of gaseous $\mathrm{NH}_{3}$ at ground surface, which is not easy to be scavenged completely during the short time fraction measurements. This is also confirmed by the larger difference in below-cloud contribution to $\mathrm{NH}_{4}^{+}$wet deposition than other ions estimated by the exponential approach and the average approach in Table 2. As mentioned above, more and longer fraction measurements as well as studies on the influence of $\mathrm{NH}_{3}$ to $\mathrm{NH}_{4}^{+}$wet deposition are needed in the future.

Following Eq. (2), the contributions of below-cloud scavenging to the wet deposition in each rainfall event from 2014-2017 are estimated from the in-cloud concentration. Figure 5 shows the yearly VWA of SNA and $\mathrm{Ca}^{2+}$ and the in-cloud and below-cloud contributions. The ratio of belowcloud contribution to the four major components based on the yearly median value of the in-cloud concentration is also shown in Fig. 5. Benefiting from the Action Plan, the air quality at the surface layer have been significantly improved (Zhang et al., 2019), which in turn leads to the decreases in the below-cloud scavenging. In this study, it also shows that the below-cloud contributions of $\mathrm{SO}_{4}^{2-}, \mathrm{NO}_{3}^{-}, \mathrm{NH}_{4}^{+}$, and $\mathrm{Ca}^{2+}$ decrease from $>50 \%$ in 2014 to $\sim 40 \%$ in 2017 . In 2017, the contribution of below-cloud scavenging declines to lower than $40 \%$ for $\mathrm{SO}_{4}^{2-}$ and $\mathrm{NH}_{4}^{+}$, but remains at $44 \%$ for $\mathrm{NO}_{3}^{-}$. Over the four-year period from 2014-2017, the average yearly wet deposition for all ions and the below-cloud wet scavenging contributions are given in Table 2. Similar to the concentrations in precipitation, the wet deposition of $\mathrm{SO}_{4}^{2-}, \mathrm{NO}_{3}^{-}$, and $\mathrm{NH}_{4}^{+}$decreased from $21.5 \mathrm{~kg} \mathrm{Sha}^{-1} \mathrm{yr}^{-1}$, 8.9, and $19.0 \mathrm{~kg} \mathrm{Nha}^{-1} \mathrm{yr}^{-1}$ from 2007-2010 (Pan et al., 2012, 2013) and to $11.4 \mathrm{~kg} \mathrm{Sha}^{-1} \mathrm{yr}^{-1}$ $\left(3.42 \times 10^{3} \mathrm{mg} \mathrm{m}^{-2} \mathrm{yr}^{-1}\right), \quad 6.9$, and $16.7 \mathrm{~kg} \mathrm{Nha}^{-1} \mathrm{yr}^{-1}$ $\left(3.05 \times 10^{3}\right.$ and $\left.2.15 \times 10^{3} \mathrm{mg} \mathrm{m}^{-2} \mathrm{yr}^{-1}\right)$ from 2014-2017, respectively. Below-cloud scavenging contributed to almost half of total deposition estimated with the exponential approach $(50 \%-60 \%)$, which is higher than the average approach $(40 \%-50 \%)$.

\section{Factors influencing below-cloud scavenging}

Each precipitation event is unique in terms rainfall intensity, droplet sizes and distribution, rainfall type (thunderstorms or deep convective scavenging), air concentrations of chemical components, etc. The unique characterization of each precipitation event was considered in calculation of the proportions from in-cloud and below-cloud processes, as the exponential approach to each unique event was made. The belowcloud proportions varied from $20 \%$ to $80 \%$ among the 69 rainfall events. The influence of these factors affecting wet scavenging were investigated through the correlation analysis between below-cloud proportions with the rainfall type as well as the rainfall intensity.

\subsection{Rainfall type}

The rainfall over the North China Plain in summertime is usually determined by the synoptic system such as the upperlevel trough or the cold vortex. The 69 rainfall events have been classified based on the synoptic system according to records from the Beijing Meteorological Service (http://bj. cma.gov.cn, last access: 17 June 2021) with 33 events associated with upper-level troughs, 23 events associated with a cold vortex, and 13 events associated with other systems. Figure 6 shows the contributions of below-cloud scavenging for the two major systems. A high contribution from below-cloud scavenging is found for rainfall events associated with an upper-level trough with the median contributions for $\mathrm{SO}_{4}^{2-}, \mathrm{NO}_{3}^{-}, \mathrm{NH}_{4}^{+}$, and $\mathrm{Ca}^{2+}$ of $56.2 \%, 62.1 \%$, $56.3 \%$, and $61.9 \%$, respectively. In the contrast, the contributions during rainfall events under cold vortex conditions are significantly lower, with the values of $42.2 \%, 44.5 \%$, $41.7 \%$, and $53.9 \%$, respectively. Rainfall events associated with an upper-level trough are usually accompanied by orographic or frontal precipitation and are characterized by long and continuous precipitation (Shou et al., 2000). This suggests that below-cloud scavenging of chemical components is important for this rainfall type due to air mass transport 

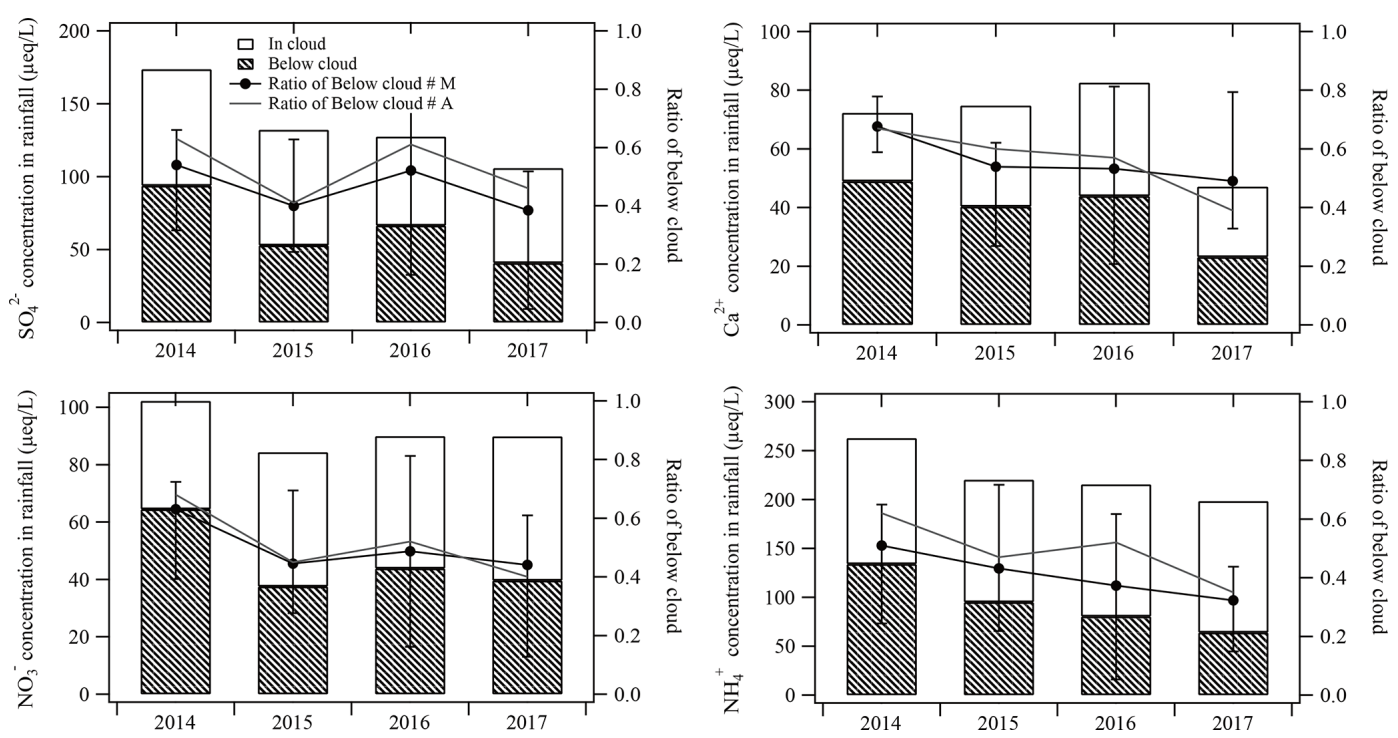

Figure 5. The annual volume weighted average below-cloud and in-cloud portion of $\mathrm{SO}_{4}^{2-}(\mathbf{a}), \mathrm{Ca}^{2+}(\mathbf{b}), \mathrm{NO}_{3}^{-}(\mathbf{c})$, and $\mathrm{NH}_{4}^{+}(\mathbf{d})$ from 2014-2017. The ratio of annual median below-cloud contribution for each component is represented as the black line in each panel. The \#M and \#A marks in the below-cloud ratio represent the estimation based on the median value and average value of in-cloud concentration in each year, while the first quartile and the third quartiles are also included in the figure.

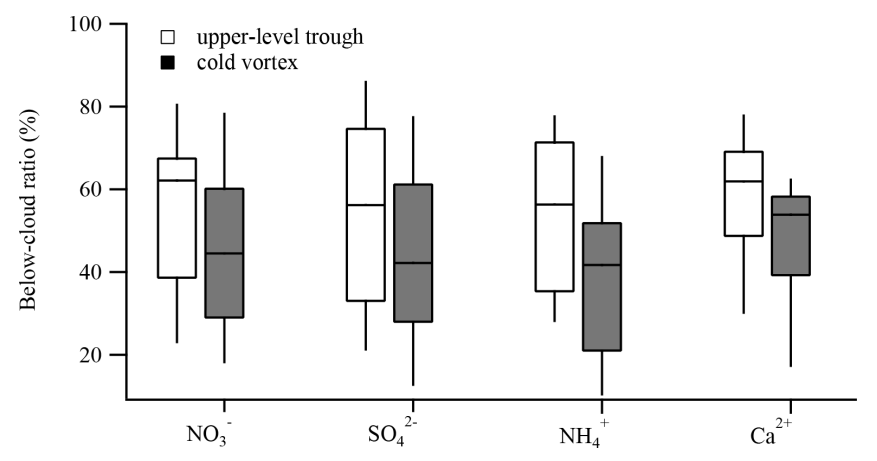

Figure 6. Contribution of below-cloud scavenging during rainfall events associated with different synoptic conditions.

from outside Beijing. In contrast, rainfall events associated with a cold vortex usually originate from strong thermal convection and are characterized by short heavy rainfall (Zhang et al., 2008; Liu et al., 2016; Zheng et al., 2020). This is common during the summer months in Beijing with deep convective clouds (Yu et al., 2011; Gao and He, 2013) and suggests that there is a large contribution from in-cloud scavenging to the total wet deposition.

\subsection{Precipitation intensity and rainfall volume}

To illustrate the impacts of rainfall on below-cloud aerosol scavenging, the relationship between the below-cloud fraction and the rainfall volume and precipitation intensity are investigated (see Fig. 7). Negative correlations in the belowcloud fraction are found for both the rainfall volume and precipitation intensity, although the relationship with the former is stronger ( $R$ : $0.63-0.93$ vs. $0.03-0.64)$. This is consistent with the results for 2014 in Beijing reported by Xu et al. (2017). Atmospheric particles are efficiently removed below cloud by washout at the beginning of precipitation events (almost $70 \%$ of SNA is removed in the first two to three fractions, as shown in Fig. 1). As the rainfall progresses, in-cloud scavenging makes an increasingly important contribution as below-cloud aerosol concentrations fall. Xu et al. (2017) found that heavy summertime rainfall events with more than $40 \mathrm{~mm}$ of rainfall usually occur over very short periods of time, usually $2-3 \mathrm{~h}$. This heavy rainfall leads to the scavenging of aerosols in a relatively localized region and prevents the compensation associated with transport of air pollutants from outside the region during longer-duration light rainfall events. This contributes to the decreased contribution of below-cloud scavenging during the high intensity rainfall events.

\section{Conclusions}

This paper presents an analysis of below-cloud scavenging from 4 years of sequential sampling of rainfall events in Beijing from May of 2014 to November of 2017. The concentra- 

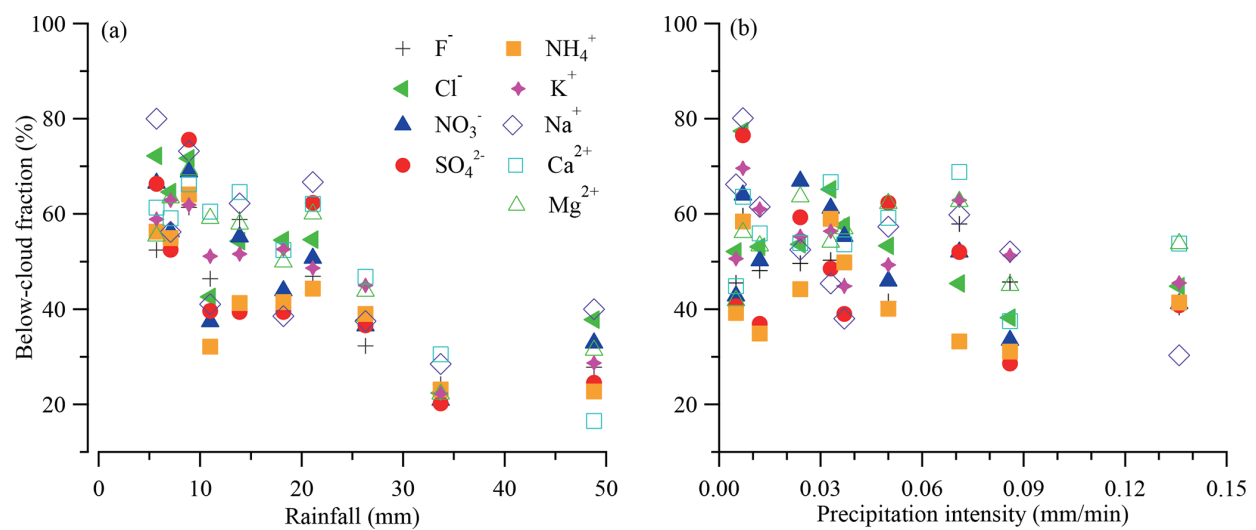

Figure 7. Contribution of below-cloud scavenging in events with different rainfall volume and precipitation intensity.

tion of ions in precipitation varied dramatically, with yearly volume weighted averaged concentrations of $\mathrm{SO}_{4}^{2-}, \mathrm{NO}_{3}^{-}$, $\mathrm{NH}_{4}^{+}$, and $\mathrm{Ca}^{2+}$ decreasing by $39 \%, 12 \%, 25 \%$, and $35 \%$ between 2014 and 2017, respectively. Due to faster decreases in $\mathrm{SO}_{4}^{2-}$ than $\mathrm{NO}_{3}^{-}$, both in precipitation and in the air during the observation period, there is a significant decrease in the $\mathrm{S} / \mathrm{N}$ ratio in precipitation at $44 \%$ and in air at $48 \%$. Benefiting from the national Air Pollution Prevention and Control Action Plan, sulfur has been further reduced, while nitrogen, especially nitrate, needs further attention in the next action plan to prevent deterioration of the environment associated with acid rain and photochemical pollution.

A new method has been developed and employed to estimate the below-cloud contribution to wet deposition in Beijing. The new approach suggests that the contribution from below-cloud scavenging is greater than that estimated by applying simpler approaches used in previous studies. Overall, the contribution of below-cloud scavenging to the wet deposition of the four major components is important at $50 \%-$ $60 \%$. The contribution of below-cloud scavenging shows a decrease over the 2014-2017 period for $\mathrm{Ca}^{2+}, \mathrm{SO}_{4}^{2-}$, and $\mathrm{NH}_{4}^{+}$, but little change for $\mathrm{NO}_{3}^{-}$from 2015-2017. Belowcloud scavenging also has a strong cleansing effect on air pollution, and the hourly concentration of $\mathrm{PM}_{2.5}$ is found to decrease sharply as the rainfall events occur, even when the effects from wind have been accounted for.

Rainfall types also influence the contribution of belowcloud scavenging. Seventy-five rainfall events during the four-year period were classified based on the local synoptic conditions. Lower contributions from below-cloud scavenging $(\sim 40 \%)$ are found for the four major ions in rainfall events associated with a cold vortex, while higher contributions $(\sim 60 \%)$ are associated with an upper-level trough. Precipitation volume and intensity both show a negative correlation with the below-cloud fraction. This suggests that atmospheric particles are efficiently removed via belowcloud scavenging processes at the beginning of precipitation events. As the event progresses, rainfall in the later fractions shows a greater contribution from in-cloud scavenging processes as aerosols in the surface layer have already been removed. To better understand the mechanism of below-cloud scavenging processes, high-resolution measurements both in precipitation and in the air, especially at the beginning of rainfall events, are needed in the future.

Data availability. To request the observed data for scientific research purposes, please contact Baozhu $\mathrm{Ge}$ at the Institute of Atmospheric Physics, Chinese Academy of Sciences, via email (gebz@mail.iap.ac.cn).

Supplement. The supplement related to this article is available online at: https://doi.org/10.5194/acp-21-9441-2021-supplement.

Author contributions. BG and ZW designed the whole structure of this work and prepared the manuscript with contributions from all co-authors. DX, XY, JW, and QT helped with the data processing. $\mathrm{OW}, \mathrm{XC}$, and $\mathrm{XP}$ were involved in the scientific interpretation and discussion.

Competing interests. The authors declare that they have no conflict of interest.

Acknowledgements. We acknowledge the CNEMC for providing the data of the six criteria pollutants in Beijing. We also acknowledge the Beijing Municipal Environmental Monitoring Center for providing the aerosol components data in Beijing.

Financial support. This work is supported by the National Natural Science Foundation of China (grant nos. 41877313, 91744206, 41620104008), the National Key Research and Development Plan (grant no. 2018YFC0830802), the Priority Research Program of 
CAS (grant no. XDA19040204) and the UK Natural Environment Research Council (NE/N0006925/1).

Review statement. This paper was edited by Leiming Zhang and reviewed by two anonymous referees.

\section{References}

Aikawa, M. and Hiraki, T.: Washout/rainout contribution in wet deposition estimated by $0.5 \mathrm{~mm}$ precipitation sampling/analysis, Atmos. Environ., 43, 4935-4939, 2009.

Aikawa, M., Kajino, M., Hiraki, T., and Mukai, H.: The contribution of site to washout and rainout: Precipitation chemistry based on sample analysis from $0.5 \mathrm{~mm}$ precipitation increments and numerical simulation, Atmos. Environ., 95, 165-174, https://doi.org/10.1016/j.atmosenv.2014.06.015, 2014.

Andronache, C.: Estimated variability of below-cloud aerosol removal by rainfall for observed aerosol size distributions, Atmos. Chem. Phys., 3, 131-143, https://doi.org/10.5194/acp-3131-2003, 2003.

Andronache, C.: Estimates of sulfate aerosol wet scavenging coefficient for locations in the Eastern United States, Atmos. Environ., 38, 795-804, https://doi.org/10.1016/j.atmosenv.2003.10.035, 2004a.

Andronache, C.: Precipitation removal of ultrafine aerosol particles from the atmospheric boundary layer, J. Geophys. Res.-Atmos., 109, 795-804, https://doi.org/10.1016/j.atmosenv.2003.10.035, 2004b.

Bae, S. Y., Jung, C. H., and Kim, Y. P.: Derivation and verification of an aerosol dynamics expression for the below-cloud scavenging process using the moment method, J. Aerosol. Sci., 41, 266-280, 2010.

Bae, S. Y., Park, R. J., Yong, P. K., and Woo, J. H.: Effects of belowcloud scavenging on the regional aerosol budget in East Asia, Atmos. Environ., 58, 14-22, 2012.

Barth, M. C., Rasch, P. J., Kiehl, J. T., Benkovitz, C. M., and Schwartz, S. E.: Sulfur chemistry in the National Center for Atmospheric Research Community Climate Model: Description, evaluation, features, and sensitivity to aqueous chemistry, J. Geophys. Res.-Atmos., 105, 1387-1415, 2000.

Bertrand, G., Celle-Jeanton, H., Laj, P., Rangognio, J., and Chazot, G.: Rainfall chemistry: long range transport versus below cloud scavenging. A two-year study at an inland station (Opme, France), J. Atmos. Chem., 60, 253-271, 2008.

Chate, D. M., Rao, P. S. P., Naik, M. S., Momin, G. A., Safai, P. D., and Ali, K.: Scavenging of aerosols and their chemical species by rain, Atmos. Environ., 37, 2477-2484, https://doi.org/10.1016/S1352-2310(03)00162-6, 2003.

Chen, L., Gao, Y., Zhang, M., Fu, J. S., Zhu, J., Liao, H., Li, J., Huang, K., Ge, B., Wang, X., Lam, Y. F., Lin, C.-Y., Itahashi, S., Nagashima, T., Kajino, M., Yamaji, K., Wang, Z., and Kurokawa, J.: MICS-Asia III: multi-model comparison and evaluation of aerosol over East Asia, Atmos. Chem. Phys., 19, 11911-11937, https://doi.org/10.5194/acp-19-11911-2019, 2019.

ENVIRON.INC.: User's Guide Comperhensive Air Quality Model with Extension (CAMx) Version 4.42, 101 Rowland Way, Suite 220, Novato, California, 2005.
Feng, J.: A size-resolved model for below-cloud scavenging of aerosols by snowfall, J. Geophys. Res., 114, D08203, https://doi.org/10.1029/2008jd011012, 2009.

Gao, Y. and He, L. F.: The phase features of a cold vortex over north China (in English abstract), J. Appl. Meteor. Sci., 24, 704-713, 2013.

Ge, B., Wang, Z., Gbaguidi, A. E., and Zhang, Q.: Source Identification of Acid Rain Arising over Northeast China: Observed Evidence and Model Simulation, Aerosol Air Qual. Res., 16, 13661377, https://doi.org/10.4209/aaqr.2015.05.0294, 2016.

Ge, B., Itahashi, S., Sato, K., Xu, D., Wang, J., Fan, F., Tan, Q., Fu, J. S., Wang, X., Yamaji, K., Nagashima, T., Li, J., Kajino, M., Liao, H., Zhang, M., Wang, Z., Li, M., Woo, J.-H., Kurokawa, J., Pan, Y., Wu, Q., Liu, X., and Wang, Z.: Model Inter-Comparison Study for Asia (MICS-Asia) phase III: multimodel comparison of reactive nitrogen deposition over China, Atmos. Chem. Phys., 20, 10587-10610, https://doi.org/10.5194/acp-20-105872020, 2020.

Goncalves, F. L. T., Ramos, A. M., Freitas, S., Dias, M. A. S., and Massambani, O.: In-cloud and below-cloud numerical simulation of scavenging processes at Serra Do Mar region, SE Brazil, Atmos. Environ., 36, 5245-5255, 2002.

Henzing, J. S., Olivié, D. J. L., and van Velthoven, P. F. J.: A parameterization of size resolved below cloud scavenging of aerosols by rain, Atmos. Chem. Phys., 6, 3363-3375, https://doi.org/10.5194/acp-6-3363-2006, 2006.

Hicks, B. B.: A climatology of wet deposition scavenging ratios for the United States, Atmos. Environ., 39, 1585-1596, 2005.

Huang, M., Shen, Z., and Liu, S.: A study on the formation processes of acid rain in some areas of Southwest China, Scientia Atmopherica Sinica, 19, 359-366, 1995 (in Chinese).

Itahashi, S., Yumimoto, K., Uno, I., Hayami, H., Fujita, S.-I., Pan, Y., and Wang, Y.: A 15-year record (2001-2015) of the ratio of nitrate to non-sea-salt sulfate in precipitation over East Asia, Atmos. Chem. Phys., 18, 2835-2852, https://doi.org/10.5194/acp18-2835-2018, 2018.

Itahashi, S., Ge, B., Sato, K., Fu, J. S., Wang, X., Yamaji, K., Nagashima, T., Li, J., Kajino, M., Liao, H., Zhang, M., Wang, Z., Li, M., Kurokawa, J., Carmichael, G. R., and Wang, Z.: MICSAsia III: overview of model intercomparison and evaluation of acid deposition over Asia, Atmos. Chem. Phys., 20, 2667-2693, https://doi.org/10.5194/acp-20-2667-2020, 2020.

Kajino, M. and Aikawa, M.: A model validation study of the washout/rainout contribution of sulfate and nitrate in wet deposition compared with precipitation chemistry data in Japan, Atmos. Environ., 117, 124-134, https://doi.org/10.1016/j.atmosenv.2015.06.042, 2015.

Kasper-Giebl, A., Kalina, M. F., and Puxbaum, H.: Scavenging ratios for sulfate, ammonium and nitrate determined at $\mathrm{Mt}$ Sonnblick (3106 m asl), Atmos. Environ., 33, 895-906, 1999.

Kong, L., Tang, X., Zhu, J., Wang, Z., Fu, J. S., Wang, X., Itahashi, S., Yamaji, K., Nagashima, T., Lee, H.-J., Kim, C.-H., Lin, C.-Y., Chen, L., Zhang, M., Tao, Z., Li, J., Kajino, M., Liao, H., Wang, Z., Sudo, K., Wang, Y., Pan, Y., Tang, G., Li, M., Wu, Q., Ge, B., and Carmichael, G. R.: Evaluation and uncertainty investigation of the $\mathrm{NO}_{2}, \mathrm{CO}$ and $\mathrm{NH}_{3}$ modeling over China under the framework of MICS-Asia III, Atmos. Chem. Phys., 20, 181-202, https://doi.org/10.5194/acp-20-181-2020, 2020. 
Li, R., Cui, L., Zhao, Y., Zhang, Z., Sun, T., Li, J., Zhou, W., Meng, Y., Huang, K., and Fu, H.: Wet deposition of inorganic ions in 320 cities across China: spatio-temporal variation, source apportionment, and dominant factors, Atmos. Chem. Phys., 19, 11043 11070, https://doi.org/10.5194/acp-19-11043-2019, 2019.

Liu, X. M., Zhang, M. J., Wang, S. J., Zhao, P. P., Wang, J., and Zhou, P. P.: Estimation and analysis of precipaitation cloud base height in China (in English abstract), Meteor. Mon., 42, 11351145, 2016.

Malaguti, A., Mircea, M., La Torretta, T. M. G., Telloli, C., Petralia, E., Stracquadanio, M., and Berico, M.: Comparison of Online and Offline Methods for Measuring Fine Secondary Inorganic Ions and Carbonaceous Aerosols in the Central Mediterranean Area, Aerosol Air Qual. Res., 15, 2641-2653, 2015.

Markovic, M. Z., VandenBoer, T. C., and Murphy, J. G.: Characterization and optimization of an online system for the simultaneous measurement of atmospheric water-soluble constituents in the gas and particle phases, J. Environ. Monitor., 14, 1872-1884, 2012.

Okita, T., Hara, H., and Fukuzaki, N.: Measurements of atmospheric $\mathrm{SO}_{2}$ and $\mathrm{SO}_{4}^{2-}$, and determination of the wet scavenging coefficient of sulfate aerosols for the winter monsoon season over the Sea of Japan, Atmos. Environ., 30, 3733-3739, 1996.

Ouyang, W., Guo, B. B., Cai, G. Q., Li, Q., Han, S., Liu, B., and Liu, X. G.: The washing effect of precipitation on particulate matter and the pollution dynamics of rainwater in downtown Beijing, Sci. Total Environ., 505, 306-314, 2015.

Pan, Y. P., Wang, Y. S., Tang, G. Q., and Wu, D.: Wet and dry deposition of atmospheric nitrogen at ten sites in Northern China, Atmos. Chem. Phys., 12, 6515-6535, https://doi.org/10.5194/acp12-6515-2012, 2012.

Pan, Y. P., Wang, Y. S., Tang, G. Q., and Wu, D.: Spatial distribution and temporal variations of atmospheric sulfur deposition in Northern China: insights into the potential acidification risks, Atmos. Chem. Phys., 13, 1675-1688, https://doi.org/10.5194/acp13-1675-2013, 2013.

Pan, Y. P., Tian, S. L., Zhao, Y. H., Zhang, L., Zhu, X. Y., Gao, J., Huang, W., Zhou, Y. B., Song, Y., Zhang, Q., and Wang, Y. S.: Identifying Ammonia Hotspots in China Using a National Observation Network, Environ. Sci. Technol., 52, 3926-3934, https://doi.org/10.1021/acs.est.7b05235, 2018.

Pu, W. W., Quan, W. J., Ma, Z. L., Shi, X. F., Zhao, X. J., Zhang, L. N., Wang, Z. F., and Wang, W. Y.: Long-term trend of chemical composition of atmospheric precipitation at a regional background station in Northern China, Sci. Total Environ., 580, 13401350, 2017.

Seinfeld, J. H. and Pandis, S. N.: Atmospheric chemistry and physics: from air pollution to climate change, Wiley, New York, 2006.

Shou, S. W., Zhu, Q. G., Lin, J. R., and Tang, D. S.: The principles and methods of weather science, China Meteorological Press, Beijing, 76-81, 2000.

Sportisse, B.: A review of parameterizations for modelling dry deposition and scavenging of radionuclides, Atmos. Environ., 41, 2683-2698, https://doi.org/10.1016/j.atmosenv.2006.11.057, 2007.

State Council of the People's Republic of China: Notice of the general office of the state council on issuing the air pollution prevention and control action plan, available at: http://www.gov.cn/ zwgk/2013-09/12/content_2486773.htm, last access: 21 August 2019.

Sun, Y. L., Wang, Z. F., Du, W., Zhang, Q., Wang, Q. Q., Fu, P. Q., Pan, X. L., Li, J., Jayne, J., and Worsnop, D. R.: Longterm real-time measurements of aerosol particle composition in Beijing, China: seasonal variations, meteorological effects, and source analysis, Atmos. Chem. Phys., 15, 10149-10165, https://doi.org/10.5194/acp-15-10149-2015, 2015.

Tan, J., Fu, J. S., Carmichael, G. R., Itahashi, S., Tao, Z., Huang, K., Dong, X., Yamaji, K., Nagashima, T., Wang, X., Liu, Y., Lee, H.-J., Lin, C.-Y., Ge, B., Kajino, M., Zhu, J., Zhang, M., Liao, H., and Wang, Z.: Why do models perform differently on particulate matter over East Asia? A multi-model intercomparison study for MICS-Asia III, Atmos. Chem. Phys., 20, 7393-7410, https://doi.org/10.5194/acp-20-7393-2020, 2020.

Tang, A. H., Zhuang, G. S., Wang, Y., Yuan, H., and Sun, Y. L.: The chemistry of precipitation and its relation to aerosol in Beijing, Atmos. Environ., 39, 3397-3406, https://doi.org/10.1016/j.atmosenv.2005.02.001, 2005.

Tang, J., Xu, X., Ba, J., and Wang, S.: Trends of the precipitation acidity over China during 1992-2006, Chinese. Sci. Bul., 5, 1800-1807, https://doi.org/10.1007/s11434-009-3618-1, 2010.

Tang, J. C. H. B., Yu, X. L., Wang, S., Yao, P., Lv, B., Xu, X. B., and Ding, G.: Evaluation of results of station inter-comparison with blind samples in Acid Rain Monitoring Network in China, Meteor. Mon., 33, 75-83, 2007 (with English abstract).

Textor, C., Schulz, M., Guibert, S., Kinne, S., Balkanski, Y., Bauer, S., Berntsen, T., Berglen, T., Boucher, O., Chin, M., Dentener, F., Diehl, T., Easter, R., Feichter, H., Fillmore, D., Ghan, S., Ginoux, P., Gong, S., Grini, A., Hendricks, J., Horowitz, L., Huang, P., Isaksen, I., Iversen, I., Kloster, S., Koch, D., Kirkevåg, A., Kristjansson, J. E., Krol, M., Lauer, A., Lamarque, J. F., Liu, X., Montanaro, V., Myhre, G., Penner, J., Pitari, G., Reddy, S., Seland, Ø., Stier, P., Takemura, T., and Tie, X.: Analysis and quantification of the diversities of aerosol life cycles within AeroCom, Atmos. Chem. Phys., 6, 1777-1813, https://doi.org/10.5194/acp-6-17772006, 2006.

Tian, S. L., Pan, Y. P., and Wang, Y. S.: Size-resolved source apportionment of particulate matter in urban Beijing during haze and non-haze episodes, Atmos. Chem. Phys., 16, 1-19, https://doi.org/10.5194/acp-16-1-2016, 2016.

Vet, R., Artz, R. S., Carou, S., Shaw, M., Ro, C. U., Aas, W., Baker, A., Bowersox, V. C., Dentener, F., Galy-Lacaux, C., Hou, A., Pienaar, J. J., Gillett, R., Forti, M. C., Gromov, S., Hara, H., Khodzher, T., Mahowald, N. M., Nickovic, S., Rao, P. S. P., and Reid, N. W.: A global assessment of precipitation chemistry and deposition of sulfur, nitrogen, sea salt, base cations, organic acids, acidity and pH, and phosphorus, Atmos. Environ., 93, $3-$ 100, 2014.

Wang, W. X. and Wang, T.: On acid rain formation in China, Atmos. Environ., 30, 4091-4093, 1996.

Wang, X., Zhang, L., and Moran, M. D.: Uncertainty assessment of current size-resolved parameterizations for below-cloud particle scavenging by rain, Atmos. Chem. Phys., 10, 5685-5705, https://doi.org/10.5194/acp-10-5685-2010, 2010.

Wang, X., Zhang, L., and Moran, M. D.: Development of a new semi-empirical parameterization for below-cloud scavenging of size-resolved aerosol particles by both rain and snow, 
Geosci. Model Dev., 7, 799-819, https://doi.org/10.5194/gmd-7799-2014, 2014.

Wang, Y., Xue, L. I., Li, Y. A. O., Yanan, Z., and Yuepeng, P. A. N.: Variation of $\mathrm{pH}$ and Chemical Composition of Precipitation by Multi-step Sampling in Summer of Beijing 2007, Environmental Science, 30, 2715-2721, 2009 (with English abstract).

Wang, Z. F., Xie, F. Y., Sakurai, T., Ueda, H., Han, Z. W., Carmichael, G. R., Streets, D., Engardt, M., Holloway, T., Hayami, H., Kajino, M., Thongboonchoo, N., Bennet, C., Park, S. U., Fung, C., Chang, A., Sartelet, K., and Amann, M.: MICSAsia II: Model inter-comparison and evaluation of acid deposition, Atmos. Environ., 42, 3528-3542, 2008.

Xu, D., Ge, B., Chen, X., Sun, Y., Cheng, N., Li, M., Pan, X., Ma, Z., Pan, Y., and Wang, Z.: Multi-method determination of the below-cloud wet scavenging coefficients of aerosols in Beijing, China, Atmos. Chem. Phys., 19, 15569-15581, https://doi.org/10.5194/acp-19-15569-2019, 2019.

Xu, D. H., Ge, B. Z., Wang, Z. F., Sun, Y. L., Chen, Y., Ji, D. S., Yang, T., Ma, Z. Q., Cheng, N. L., Hao, J. Q., and Yao, X. F.: Below-cloud wet scavenging of soluble inorganic ions by rain in Beijing during the summer of 2014, Environ. Pollut., 230, 963973, https://doi.org/10.1016/j.envpol.2017.07.033, 2017.

Yamagata, S., Kobayashi, D., Ohta, S., Murao, N., Shiobara, M., Wada, M., Yabuki, M., Konishi, H., and Yamanouchi, T.: Properties of aerosols and their wet deposition in the arctic spring during ASTAR2004 at Ny-Alesund, Svalbard, Atmos. Chem. Phys., 9, 261-270, https://doi.org/10.5194/acp-9-261-2009, 2009.

Yang, F., Tan, J., Shi, Z. B., Cai, Y., He, K., Ma, Y., Duan, F., Okuda, T., Tanaka, S., and Chen, G.: Five-year record of atmospheric precipitation chemistry in urban Beijing, China, Atmos. Chem. Phys., 12, 2025-2035, https://doi.org/10.5194/acp12-2025-2012, 2012.

Yu, Z. Y., He, L. F., Fan, G. Z., Li, Z. C., and Su, Y. L.: The basic features of the severe convection at the background of cold vortex over north china, J. Trop. Meteor., 27, 89-94, 2011 (with English abstract).

Yuan, W. H., Sun, W., Chen, H. M., and Yu, R. C.: Topographic effects on spatiotemporal variations of short-duration rainfall events in warm season of central North China, J. Geophys. Res.Atmos., 119, 11223-11234, 2014.
Yue, D., Hu, M., and Wu, Z.: Variation and interaction of major azotic inorganic compounds in the summer in beijing (in Chinese), Environ. Monit. China, 29, 9-14, 2013.

Zhai, S., Jacob, D. J., Wang, X., Liu, Z., Wen, T., Shah, V., Li, K., Moch, J., Bates, K. H., Song, S., Shen, L., Zhang, Y., Luo, G., Yu, F., Sun, Y., Wang, L., Qi, M., Tao, J., Gui, K., Xu, H., Zhang, Q., Zhao, T., Lee, H. C., Choi, H., and Liao, H.: Control of particulate nitrate air pollution in China, Nat. Geosci., 14, 389-395, https://doi.org/10.1038/s41561-021-00726-z, 2021.

Zhang, C., Zhang, Q., Wang, Y., and Liang, X.: Climatology of warm season cold vortices in East Asia: 1979-2005, Meteorol. Atmos. Phys., 100, 291-301, 2008.

Zhang, L., Michelangeli, D. V., and Taylor, P. A.: Numerical studies of aerosol scavenging by low-level, warm stratiform clouds and precipitation, Atmos. Environ., 38, 4653-4665, https://doi.org/10.1016/j.atmosenv.2004.05.042, 2004.

Zhang, L., Wang, X., Moran, M. D., and Feng, J.: Review and uncertainty assessment of size-resolved scavenging coefficient formulations for below-cloud snow scavenging of atmospheric aerosols, Atmos. Chem. Phys., 13, 10005-10025, https://doi.org/10.5194/acp-13-10005-2013, 2013.

Zhang, Q., Zheng, Y. X., Tong, D., Shao, M., Wang, S. X., Zhang, Y. H., Xu, X. D., Wang, J. N., He, H., Liu, W. Q., Ding, Y. H., Lei, Y., Li, J. H., Wang, Z. F., Zhang, X. Y., Wang, Y. S., Cheng, J., Liu, Y., Shi, Q. R., Yan, L., Geng, G. N., Hong, C. P., Li, M., Liu, F., Zheng, B., Cao, J. J., Ding, A. J., Gao, J., Fu, Q. Y., Huo, J. T., Liu, B. X., Liu, Z. R., Yang, F. M., He, K. B., and Hao, J. M.: Drivers of improved $\mathrm{PM}_{2.5}$ air quality in China from 2013 to 2017, P. Natl. Acad. Sci. USA, 116, 24463-24469, 2019.

Zheng, B., Tong, D., Li, M., Liu, F., Hong, C., Geng, G., Li, H., Li, X., Peng, L., Qi, J., Yan, L., Zhang, Y., Zhao, H., Zheng, Y., He, K., and Zhang, Q.: Trends in China's anthropogenic emissions since 2010 as the consequence of clean air actions, Atmos. Chem. Phys., 18, 14095-14111, https://doi.org/10.5194/acp-18-140952018, 2018.

Zheng Q., Zheng, Y. F., Wang L. W., and Du, J. Y.: Comparative Analysis of the Features of Precipitating and Nonprecipitating Ice Clouds in the Beijing-Tianjin-Hebei Region in Summer, Climatic and Environmental Research, 25, 77-89, 2020 (with English abstract). 